\title{
Seroepidemiological survey of rubella immunity among three populations in Shiraz, Islamic Republic of Iran
}

\author{
M. Doroudchi, 'A.Samsami Dehaghani, ${ }^{2}$ K. Emad ${ }^{3}$ and A.A. Ghader ${ }^{1}$
}

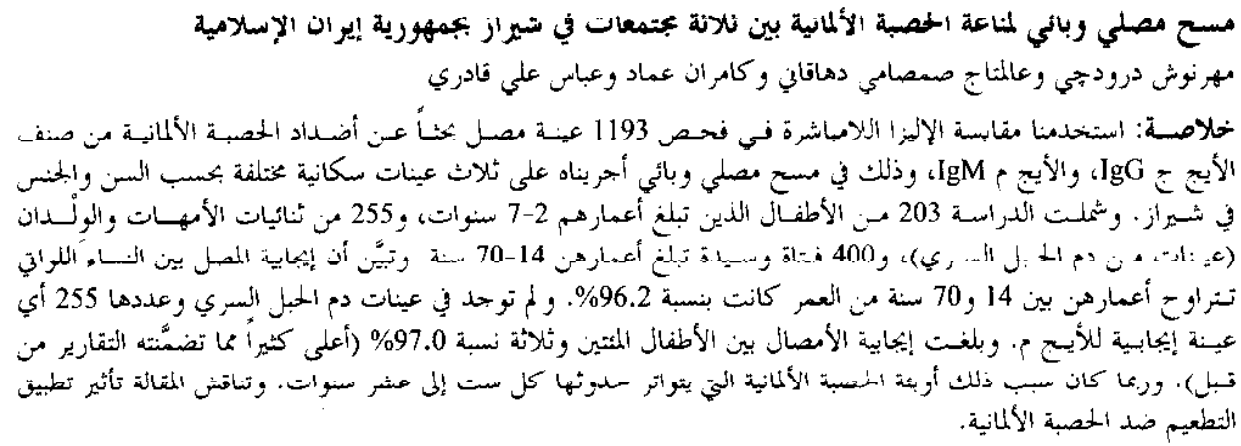

ABSTRACT We used indirect ELISA assay to test 1193 sera for rubella lgG and $\operatorname{lgM}$ antibodies in a seroepidemılogıcal survey of three age- and gender-aitrerentlated sample populations in $5 \mathrm{nIraz}$; 203 children aged 2-7 years, 255 paired mothers and meonates (cord blood) and 480 women aged 14-70 years. Seropositivity among women aged $14-70$ years was $96.2 \%$. No lgM positive case was found among the 255 tested cord blood samples. Seropositivity among the 203 children was $97.0 \%$ (much higher than previously reported). This may be due to rubella epidemics, which tend to occur every $6-10$ years. The impact of introducing rubella vaccination is discussed.

Enquâte sáro-épidémiologique sur l'immunité contre la rubéole dans trois pobulations à Chiraz (République istamique d'Iran)

RESUME Nous avons utilisé la méthode immuno-enzymatique indirecte pour tester 1193 sérums à la recherche d'anticorps lgG et d'lgM antirubéoleux dans une enquête séro-épidémiologique comprenant trois populations de l'échantillon différenciées par l'âge et le genre à Chiraz : deux cent trois (203) enfants de 2 d̀ 7 ans, 255 mères et nouveau-nés appariés (sang du cordon) et 480 femmes âgées de 14 à 70 ans. La séropositivité parmi les femmes âgées de 14 à 70 ans s'élevait à $96,2 \%$. Aucun cas lgM positif n'a été trauvé dans les 255 échantillons de sang de cordon testés. La séropositivité parmi les 203 enfants s'élevait à $97,0 \%$ (oien superieure a ce qui avalt été sıgnalé précédemment). Ceci peut être dú aux épidérnies de rubéole qui ont tendance à survenir tous les 6-10 ans. L'impact de l'introduction de la vaccination contre la rubéole fait l'objet d'un examen.

${ }^{1}$ Department of Immunology; ${ }^{2}$ Department of Obstetrics and Gynaecology; ${ }^{3}$ Department of Paediatrics, Shiraz Universify of Medical Sciences, Shiraz, Islamic Republic of Iran.

Received: 30103/00; accepted: 24/07/00

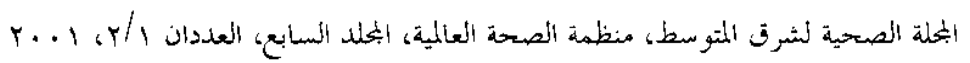




\section{Introduction}

Rubella is an exanthem disease of childhood, presenting with rash, fever and lymphadenopathy. It is a disease with a high risk of damage to the fetus. Since 1970 , comprehensive vaccination against rubella has been undertaken in industrialized countries [1]. In the past rew years, some developing countries have begun the vaccination programme against rubella [2].

Although rubella is endemic in the Islamic Republic of Iran, there is a lack of adequate information about the immune status of populations to the disease in different parts of the country. Rubella vaccination is currently not considered a health priority in the country. However, the high risk of damage to fetal organs and congenital malformations after intrauterine infection, coupled with the endemicity of the disease in the Islamic Republic of Iran, would suggest the necessity of vaccinating those at risk in the population. Selection of an appropriate, efficacious policy of vaccination is, therefore, needed. Different vaccination strategies are used in different parts of the world [3-5], including: universal vaccination of children and susceptible adults; vaccination of 15-24-month-old children, as well as children entering or ending school; and vaccination of 12-13year-old girls, and women in the postpartum period. However, in populations with high levels of natural immunity in women of childbearing age, premarital testing and vaccination of seronegative females is recommended [6].

Considerable geographic variations in the seropositivity rate for rubella because of differences in temperature have been reported by other investigators [7]. However, adequate information about immunity to the disease in different parts of the Islamic Republic of Iran is missing. The results of the few investigations undertaken reveal a high seropositivity rate, ranging from $74.8 \%$ among women of childbearing age in Ahwaz and Dezful [8] to $97.5 \%$ among children by age 15 years in Teheran [9]. However, cases of congenital rubella syndrome have been reported in Ahwaz and Dezful where high temperatures and a low seropositivity rate coexist.

In order to design an efficient and economical vaccination policy, it is necessary to have aclequate information about the immune status in different geographical parts of the country, with the different climates in different time intervals. Most of the information about rubella epidemiology in the Islamic Republic of Iran is limited to a few geographical regions in discontinuous time intervals. A major reason for this lack of information is because of the high cost of the commercial rubella kits available for such studies - the availability of homemade assays would clearly be more cost-effective. To achieve this, an indirect enzyme-linked immunosorbent assay (ELISA) was designed and standardized according to World Health Organization standard serum to perform a quantitative test. Since 1991 , when a rubella outbreak was reported in Shiraz [10], there has been no official report of seroprevalence of rubella immunoglobulins in the city. Therfore a seroepidemiological survey was performed on 1193 sera from three different pupulations according to age and sex.

\section{Methods}

\section{Blood samples}

The study population consisted of three age groups. There were 203 blood samples collected from children (ages $2-7$ years) with no major health problem referred to Shahid Rezaiee Polyclinic, Shiraz; 255 paired ma-

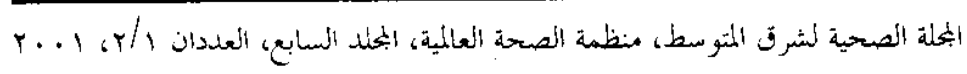


ternal and cord blood samples collected from pregnant women (ages 14-40 years); and 480 blood samples collected from women (ages 15-70 years) attending the Zeinabie Gynaecologic Clinic for routine examination. Sera were separated from blood samples on the same day of sampling, aliquoted in $0.5 \mathrm{~mL}$ volumes, and stored at $-20^{\circ} \mathrm{C}$ until use. Demographic data, including age, sex, number of children, previous abortions, abnormalities in the family and address were collected at the time of sampling.

\section{Virus culture}

Takahashi strain of rubella virus, which is used for optional vaccination in the Islamic Republic of Iran, was cultured in Vero cell line. Monolayers of vero cell line were grown in RPMI- 1640 containing $10 \%$ fetal bovine serum at $37^{\circ} \mathrm{C}$ in a $5 \%$ carbon dioxide-containing atmosphere. At the time of confluency (2-3-day-old cultures), cultures were washed with Hanks balanced salt solution, and rubella secd virus $10^{3}$ TCID50 in $2 \mathrm{~mL}$ was added. After 1 hour, adsorption at room temperature with periodic rolling, followed by 3 hours at $37^{\circ} \mathrm{C}$, maintenance medium containing $3 \%$ fetal bovine serum was added to each monolayer. Maintenance medium was replaced, 48 hours after infection, with RPMI-1640 medium without serum. To achieve high titre stocks of virus and to restrict defective interfering particles during serial un- diluted passage, rubella virus was alternatively passaged on Vero and BHK-21 cell lines $[I]$.

\section{Antigen preparation}

Detergent-solubilized whole virus preparations were prepared according to the method described by Mitchell et al. [12,13]. In brief. Takahashi strain of virus was grown on monolayers of Vero cells and harvested from culture fluids 72,96 and 120 hours after infection. Culture supernatants were pooled and clarified by centrifugation at $1000 \times \mathrm{g}$ for 20 minutes at $4{ }^{\circ} \mathrm{C}$. The clarified culture supernatant was concentrated by polyethylene glycol 6000 precipitation by adding $2.2 \%(\mathrm{w} / \mathrm{v})$ sodium chloride followed by $6 \%(\mathrm{w} / \mathrm{v})$ polyethylene glycol 6000. After overnight incubation at $4{ }^{\circ} \mathrm{C}$ with continual stirring, the fluid was pelleted by centrifugation at $1000 \times \mathrm{g}$ for 1 hour at $4^{\circ} \mathrm{C}$. The viral pellet was resuspended in proper volume of phosphatebuffered saline containing $0.5 \%$ Triton $x-100$.

Using mock-infected culture supernatant of Vero cells, a control antigen was prepared using the same procedure as rubella antigen and used in an indirect ELISA assay, including eight positive sera with different but known concentrations of antirubella IgG. Only two sera revealed an absorbance of more than 0.6 , which was equal to $20 \mathrm{IU} / \mathrm{mL}$ in the assay. However,

Table 1 Comparison of the absorbance of 8 tested sera with control and rubella antigens prepared from mock infected and rubella virus-infected culture supernatant fluid

\begin{tabular}{|c|c|c|c|c|c|c|c|c|}
\hline Reaction & Serum 1 & Serum 2 & Serum 3 & Sorum 4 & Sorum 5 & Sorum 6 & Sorum 7 & Sorum 8 \\
\hline $\begin{array}{l}\text { Reaction with } \\
\text { control antigen }\end{array}$ & 0.24 & 0.22 & 0.23 & 0.47 & 0.43 & 0.75 & 0.35 & 0.87 \\
\hline $\begin{array}{l}\text { Reaction with } \\
\text { rubella antigen }\end{array}$ & 1.30 & 1.38 & 1.28 & 1.87 & 1.59 & 1.90 & 1.33 & 1.86 \\
\hline
\end{tabular}


the reactivity of these sera with rubella antigen was much greater (Table 1).

\section{Whole virus ELISA}

Different concentrations of Triton X-100solubilized rubella antigen were titrated against negative and positive control sera of a commercial kit (Alfa Biotech, Italy) containing $0,6.25,12.5,25,50$ and 100 $\mathrm{IU} / \mathrm{mL}$ anti-rubella $\mathrm{IgG}$ to find the best concentration for antigen coating. Rubella antigen was diluted in carbonatebicarbonate buffer $(\mathrm{pH}=9.6)$ and coated onto the ELISA plate in proper concentration. Unbound antigen was washed three times with phosphate buffered saline containing $0.05 \%$ Tween 20 , and plates were blocked with phosphate buffered saline containing $1 \%$ gelatine for 1 hour at $37^{\circ} \mathrm{C}$. After the next three washes, patient sera (diluted 1:100) were added to wells and incubated at $37^{\circ} \mathrm{C}$ for 1 hour. Each plate contained a 6-point dilution series of a pooled serum, which was standardized against WHO RV-IgG reference serum (NIBSC, United Kingdom). A blank well containing phosphate buffered saline Tween 20 instead of serum was also included in each plate. Specific IgG was detected using a horseradish peroxidaseconjugated goat anti-human IgG (Calbiochem, United States of America). Optimally diluted, labelled anti-IgG was added onto ELISA plates and incubated for 15 minutes at $37^{\circ} \mathrm{C}$. After the final three washes with phosphate buffered saline Tween 20 , en7yme substrate, orthophenylene diamine dihydrochloride (DAKO, Denmark) and hydrogen peroxide in citrate buffer $(\mathrm{pH}=$ 5.5) were added in $100 \mu \mathrm{L}$ volumes. Colour development was allowed to continue for 10 minutes and then stopped by adding $50 \mu \mathrm{L}$ of $12.5 \%$ sulfuric acid solution. Absorbance was measured at $490 \mathrm{~nm}$ using an ELISA spectrophotometer (Titertecplus-
MS2 reader, Finland). Concentrations of rubella virus-specific $\mathrm{IgG}$ (IU/ $\mathrm{mL}$ ) were determined from standard curves plotted for each plate by the formula:

$$
\ln Y=\alpha_{0}+\alpha_{1} \ln X
$$

where $Y$ is absorbance value as dependent variable, $X$ is the concentration of anti-ribella IgG in sera, $\alpha_{o}$ is the $Y$ intercept and $\alpha_{1}$ is the slope of the fitted line.

Since levels of $19.0=3.7 \mathrm{IU} / \mathrm{mL}$ in the in-house whole-virus ELISA were shown to be equal to $15.3 \pm 2.4 \mathrm{IU} / \mathrm{mL}$ in the DiaMedix commercial assay [12], the level of $20 \mathrm{IU} / \mathrm{mL}$ was considered as the baseline for detection of negative cases. To detect IgM anti-rubella antibody, coating, hlocking, serum dilution and incubation times and temperatures were performed as for the IgG-rubella assay. To avoid the effect of potentially present rheumatoid factor and to remove the unwanted competition of $\lg G$ antibodies with IgM antibodies, total serum IgG was absorbed by adding goat anti-human IgG in proper dilution at the time of serum addition. Positive, negative and cut-off sera of a commercial kit (Alfa Biotech, Italy) were included in the assay. Absorbance was measured at $490 \mathrm{~nm}$ and positive and negative results were determined according to the cut-off value.

\section{Statistical methods}

The student $t$-test for unpaired and paired samples was used to compare the mean concentration of anti-rubella $\mathrm{Ig} G$ between the study groups. The chi-squared test was used to evaluate the effect of different factors on seropositivity rate. The Levene test was used to analyse the homogeneity of variances of anti-rubella IgG concentration between groups. Statistical analyses were performed using SPSS, version 6.0.

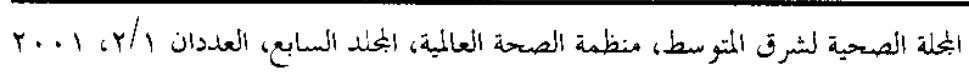




\section{Results}

In total, 735 serum samples of women aged 14-70 years and 203 serum samples from children aged 2-7 years were collected from December 8, 1998 to February 20,1999 . Of 735 female subjects, the sera of 255 pregnant mothers were also grouped with the paired cord blood sam-

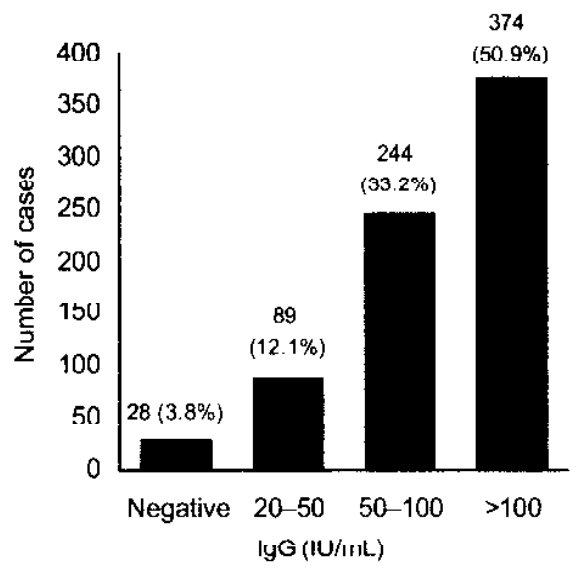

Figure 1 Anti-rubella Ig $\mathbf{G}$ concentration in women aged $14-70$ yoars. ples collected at the time of delivery. Of 643 samples with known address, 262 (40.7\%) were collected from women who lived in areas surrounding Shiraz city (rural) and $381(59.3 \%)$ from women who lived in Shiraz city itself (urban). Of 666 serum samples for which the number of children in the family was known, 513 $(77.0 \%)$ belonged to women with fewer than 3 children, $99(14.9 \%)$ belonged to women with 3-5 children and $54(8.1 \%)$ belonged to women who had 6 or more children. Among women of childbearing age, 606 had no history of abottion and 129 had at least one case of abortion ( 86 had had one, 30 had had two and 13 had had more than two). Of the 735 women, 46 reported abnormality among their children or a close relative.

\section{Seropositivity rate in women aged 14-70 years}

The rate of seropositivity among women was found to be $96.2 \%$ (707 out of 735). The average age + standard deviation of the test group was $26 \pm 8$ years and the mean $\mathrm{IgG}$ concentration was $111.13 \pm 60.79$ $\mathrm{IL} / \mathrm{mL}$. Of the 735 sera tested in this group,

Table 2 Anti-rubella lgG concentration in 643 women by age, Shiraz, islamic Republic of Iran

\begin{tabular}{lccccc}
\hline Age group (years) & No. & $\%$ & $\begin{array}{c}\text { No. } \\
\text { negative }\end{array}$ & $\begin{array}{c}\text { No. } \\
\text { positive }\end{array}$ & $\begin{array}{c}\text { IgG concentration } \\
\text { Mean } \pm s \text { (IU/mL) }\end{array}$ \\
\hline 20 & 106 & 16.5 & 3 & 103 & $112.19 \pm 58.38$ \\
$20-24$ & 229 & 35.6 & 7 & 222 & $106.76 \pm 55.37$ \\
$25-29$ & 146 & 22.7 & 4 & 142 & $104.12 \pm 5 / .32$ \\
$30-34$ & 71 & 11.0 & 4 & 67 & $114.75 \pm 71.65$ \\
$35-39$ & 45 & 7.0 & 2 & 43 & $128.41 \pm 68.40$ \\
$40-44$ & 28 & 4.4 & 0 & 28 & $116.43 \pm 61.09$ \\
$45-49$ & 10 & 1.6 & 0 & 10 & $155.46 \pm 51.02$ \\
$\geq 50$ & 8 & 1.2 & 0 & 8 & $118.62 \pm 90.36$ \\
Total & 643 & 100 & 20 & 623 & $111.31 \pm 60.21$ \\
\hline
\end{tabular}

$s=$ standard deviation. 


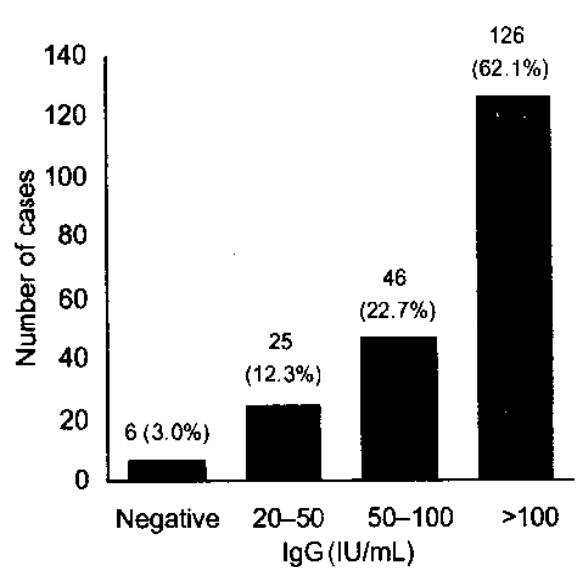

Figure 2 Anti-rubella Ig $\mathbf{G}$ concentration in cnilaren aged $2-T$ years.

28 sera $(3.8 \%)$ lad less than $20 \mathrm{IU} / \mathrm{mL}$ antirubella IgG and were therefore considered to be negative. Anti-rubella IgG concentrations among the 735 women are show $n$ Figure 1. Mean rubella-specific IgG concentration with regard to age distribution, and the frequency of positive and negative cases in each age group are shown in Table 2. No negative case was found among women aged $>40$ years. No significant difference was found between the eight age groups with regard to specific IgG concentration (Kruskal-Wallis test, $P=0.09$ ).
Of the 262 rural and 381 urban women, $9(3.4 \%)$ and $11(2.9 \%)$ respectively were negative. The difference was not statistlcally significant. However the mean concentration of rubella-specific IgG in rural cases (mean \pm standard deviation - 103.64 $\pm 61.58 \mathrm{IU} / \mathrm{mL}$ ) was significantly lower than in urban cases $(117.59 \pm 59.59 \mathrm{IU} /$ $\mathrm{mL}$ ) (Student $t$-test, $P<0.05$ ).

$A$ higher percentage of seronegativity was found in women with fewer than 3 children compared to women with 3 or more children $(3.9 \%$ versus $1.3 \%$ ), although this was not significant. The mean concentration of rubella-specific IgG in the former group was significantly lower than in the latter $(108.44 \pm 59.04 \mathrm{IU} / \mathrm{mL}$ versus $119.88 \pm 63.20 \mathrm{IU} / \mathrm{ml})(P<0.05)$.

\section{Seropositivity rate in paired mothers and cord blood samples}

The mean concentration of anti-rubella IgG in mothers' sera $(109.98 \pm 54.18 \mathrm{IU} / \mathrm{mL})$ was significantly higher than the mean concentration of anti-rubella IgG in cord blood samples $(91.39 \pm 54.03 \mathrm{IU} / \mathrm{mL}$ ) (Student $t-$ test for paired samples, $P<0.001$ ). Of 255 mothers, 2 had $<20$ IU/mL anti-rubella IgG and were thus considered negative. However, the number of negative cases was higher (10 out of 255) among nconates. Of the seronegative neonates, two were born of mothers who were seronegative, and

Table 3 Comparison of anti-rubella IgG in mothers' sera and the corresponding cord sera $(n=$ 255)

\begin{tabular}{|c|c|c|c|c|c|c|c|c|}
\hline \multirow[t]{3}{*}{ Source } & \multicolumn{8}{|c|}{ Anti-rubella loG (IU/mL) } \\
\hline & \multicolumn{2}{|c|}{$<20$} & \multicolumn{2}{|c|}{$20-50$} & \multicolumn{2}{|c|}{$50-100$} & \multicolumn{2}{|c|}{100} \\
\hline & No. & $\%$ & No. & $\%$ & No. & $\%$ & No. & $\%$ \\
\hline Mothers' blood & 2 & 0.78 & 25 & 9.80 & 97 & 38.04 & 131 & 51.31 \\
\hline Cord blood & 10 & 3.92 & 58 & 22.74 & 84 & 32.94 & 103 & 40.93 \\
\hline
\end{tabular}

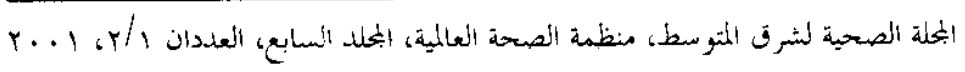


were in the youngest age group (i.e. $<20$ years old). The eight others were born of mothers with anti-rubella IgG concentration of $<50 \mathrm{IU} / \mathrm{mL}$. A comparison of the representative data for mothers and neonates is shown in Table 3 .

\section{Seropositivity rate among children aged 2-7 years}

The mean age \pm standard deviation was 4.5 \pm 1 years. The seropositivity rate in the children was $97 \%$ and the mean concentration of specific IgG was $131.21 \pm 71.24$ $\mathrm{IU} / \mathrm{mL}$. Of 203 serum samples in this age group, $6(3.0 \%)$ had an anti-rubella IgG concentration of $<20 \mathrm{IU} / \mathrm{mL}$ (Figure 2 ). Of these, 5 of $102(4.9 \%)$ were males and 1 of $101(1.0 \%)$ was female. However, the observed difference was not significant. The mean concentration of anti-rubella IgG for males was $136.06 \pm 73.95 \mathrm{IU} / \mathrm{mL}$, compared to $127.61 \pm 67.72 \mathrm{IU} / \mathrm{mL}$ for females.

\section{Comparison of the rubolla-epecific IgG in women (group 1) and children (group 3)}

The mean concentration of anti-nubella IgG in women's sera was significantly lower than in children's sera $(111.13 \mathrm{IU} / \mathrm{mL}$ compared to $131.21 \mathrm{IU} / \mathrm{mL}$ ). In addition, the distribution of $\operatorname{lgG}$ concentrations around the mean was significantly different between these groups (Levene test of homogeneity, $P<0.05$ ). In this regard, the variation in anti-rubella IgG concentration in children was significantly higher than in women.

\section{Anti-rubella IgM determination in cord blood samples}

To assess possible rubella infection of the neonates, 255 cord blood samples were tested in an IgM-ELISA assay. No IgMpositive case was detected.

\section{Discussion}

The observed $96.2 \%$ seropositivity rate among women of childbearing age is comparable to the reported prevalences of $93 \%$ [14] and $94.9 \%$ [15] of the same age group in the Islamic Republic of Iran. Since the study population was from a low socjoeconomic population. the high seronositivity rate is not unexpected. Saidi et al, reported the seropositivity rate in a low socioeconomic group to be as high as $99 \%$. compared to $92 \%$ in the high socioeconomic group in their study [14]. In a study between 1993 and 1995, Modarres et al. teported seropositivity to be $96.5 \%$ in a low socioeconomic group compared to $93 \%$ in the high socioeconomic group [15]. The rate of seroposituvity in our study is also comparable to Saudi Arabia $[16,17]$, Kuwait [18], Nigeria [19], Bahrain [20], Gambia [21], Turkey [22] and India [23]. However, it is much higher than the reported prevalence in Taiwan [24,25], Angola and Ghana [26].

The frequency of seropositivity in urban participants was slightly higher than in rural participants ( $97.1 \%$ yersus $96.6 \%$ ), but this was not statistically significant. This might be due to the fact that the rural participants were from villages very close to Shiraz, and the same factors involved in the spread of the virus in the city would also have influenced the epidemiology of the disease in these areas. In addition, the mean anti-rubella IgG concentration was significantly lower in rural participants compared to urban participants. Similarly, Saidi reported a lower haemagglutinationinhibition titre in rural cases compared to urban cases $(1: 138$ versus $1: 165)[14]$.

In previous studies, family density had been reported to influence the level of rubella antibody [5]. In the present study, the mean IgG concentration in women with

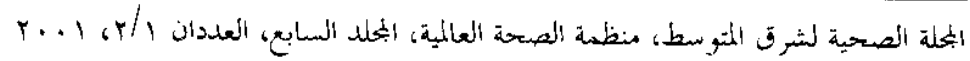


fewer than 3 children was lower than those with 3 or more children.

The mean concentration of anti-rubella IgG in cord sera was significantly lower $(P<0.001)$ than that of mothers' sera. Also, the frequency of seronegative cases was found to be significantly higher in cord blood samples. There were eight low positive and two seronegative mothers who gave birth to neonates who were seronegative. This lack of transmission of specific antibodies has been previously reported for measles and tetanus [27]. In a study of transplacental transfer of toxoplasmosis antibodics among Europcan and African cord-mother pairs, a lack of transfer was found among African, but not European pairs [28]. Shortridge and Osmund [20] reported the incidence of maternally acquired rubella antibody to be $84 \%$ for the Chinese nopulation and $90 \%$ for Caucasians in Hong Kong. They also reported a decrease in this incidence to $54 \%$ in Chinese, but not Caucasians, by 2 months. In this regard, the higher concentrations of rubella and measles antibodies in North American or European mother-neonate pairs have been reported in cord blood samples [30]. Ethnic differences and differences in level of specific antibody have been considered possible explanations for these inconsistencjes $[27,31]$. In African mothers who had high levels of antibody and who lived in countries with a high endemicity rate of infectious diseases, higher levels of tetanus antibody revealed a positive correlation with lack of antibody transfer to the fetus [28]. However, in our study we found the opposite to be the case for the transfer of rubella antibody.

The seropositivity rate among children aged 2-7 years was found to be $97 \%$, much higher than previous reports. Saidi reported a rate of $58 \%$ for the same age group [14]. In 1970, Naficy et al. reported a rate of $46.5 \%$ [9] and in 1996, Modarres et al. reported a rate of $50 \%$ for the age group of $1-10$ years [15]. The rate of seropositivity among children $<10$ years of age in Shiraz had been reported as $46.5 \%$ during 1986-90 [10]. However, the authors reported evidence of an outbreak in 1991 in Shiraz, through which the rate of seropositivity increased to $94.5 \%$. There is no official report on the duration of rubella uubreaks in the Islanic Republic of Iran. However, it can be seen from reports from the United States of America and United Kingdom in the pre-vaccination era, that rubella outbreaks seem to appear in 6-9year cycles. Since the present study was undertaken 8 years after the abovementioned report, it is likely that we faced another outbreak in Shiraz during the sampling period. It is noteworthy that greater variation in the concentration of anti-rubella IgG was found among children than among the women's group. This variation might be due to an active immunological response among children who faced rubella virus for the first time.

In the few reports of the seroepidemiology of rubella from different parts of the country, prevalence rates of $70 \%$ to more than $95 \%$ are reported among women of childbearing age $[8,9,10,14,15]$. It seems that in the highly populated urban areas with temperate climates, most of the girls develop anti-rubella IgG by the age of 15 years $[9,14,15]$. In our study, the seropositivity rate (96.2\%) among women in an urban setting with a temperate climate was much higher than the rate reported in Ahwaz and Dezfal $(74.8 \%)$, a hot area of the country [8]. However, our results are comparable with rates reported from other areas of the country with a temperate climate [15].

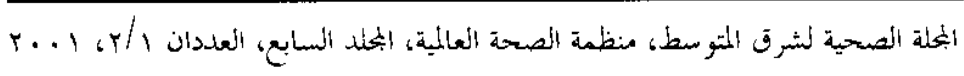


To date, rubella vaccination has not been considered a health priority in the Islamic Republic of Iran. However, due to highly variable climate in different parts of the country, deciding on a "yes" or "no" vaceination policy might be reconsidered. It should be noted that most of the studies from which information about Iranian seropositivity rates are drawn are from urban areas with temperate climate. However, in some parts of the country, lifestyles are completely different from urban and even rural life. Some migrating tribes are not settled in a defined place. No data exist about rubella immunity in such tribes.

Previous investigations have shown that the age incidence of rubella infection in the Islamic Republic of Iran is low $[14,15]$. The introduction of vaccination in other parts of the world has been accompanied by a shift in the age incidence of rubella infection to older age groups [I]. The age of women at marriage in many parts of the Islamic Republic of Iran, especially in rural areas, is low (12-17 years of age). Unless vaccinalion of all at-risk populations is undertaken, any immunization programme would change the pattern of rubella epidemiology such that the risk of infection for older groups may increase, and the risk of reinfection with wild strains after vaccination may arise.

\section{Acknowledgement}

We would like to thank Mr Mehdi Muhammadi of the Biostatistics Department of Shiraz University of Medical Sciences for his generous cooperation in performing the statistical analyses.

\section{References}

1. Rubella and congenital rubella - United States, 1984-1986. Morbidity and mortality weekly report, 1907, 30.604-70.

2. World Health Organization. Expanded programme on immunization (EPI). Weekly epidemiological record, 1996, 23:173-80.

3. Gale JL et al. The epidemiology of rubella in Taiwan. II. 1968-7969 epıdemic. International journal of epidemiology, $1972,1: 253-60$.

4. Jackson BM et al. An epidemiologic investigation of a rubella outbreak among the Amish of north-eastern Ohio. Public hoolth roports, 1003, 108:436-9.

5. Preblud $S R$ et al. Rubella vaccination in the United States: a ten-year review. Epidemiologic neviews, 1900, 2:171-94.
6. Hathout $\mathrm{H}$ et al. Seroepidemiology of rubella in Kuwait: an alternative vaccination pollcy. International fournal of eptdemiology, 1978, 7:49-53.

7. Best JM et al. New Japanese rubella vaccine: comparative trials. British medical joumal, 1974, 3:221-4.

8. Pakzad P, Ghafourian M. Rubella survey among pregnant women and congenitally infected infants in Khouzestan province Medical journal of Ahwaz. Univorsity of Modical Soionocs, 1006, 19:56-66.

9. Naficy K, Saidi S. Serological survey on viral antibodies in Iran. Tropical and geographical medicine, 1970, 22:1838. 
10. Kabiri M, Moattari A. The rubella immunosurveillance of Iranian females: an indicalion of the entergence of rubella outbreak in Shiraz, Iran. Iranian journal of medical sciences, 1993, 18:134-7.

11. Terry GM et al. Rubella virus RNA: effect of high multiplicity passage. Archives of virology, 1985, 86:29-36.

12. Mitchell LA et al. Characterization of rubella vitus-specific antibody responses by using a new synthetic peptide-based enzyme-linked immunosorbent assay. Journal of clinical microbiology, 1992, 30:1841-7.

13. Zhang $D X$ et al. Detection of rubella virus-specific immunoglobulin $G$ ( $\mathrm{lgG}$ ), $\lg M$, and $\lg A$ antibodies by immunoblot assays. Journal of clinical microbiology, 1992, 30:824-30.

14. Saidi S. Epidemiological survey of rubella immunity in Iran. Bulletin of the World Health Organization, 1972, 46:563-5.

15. Modarres S, Modarres S, Oskoii NN. The immunify of children and adult females to rubella virus infection in Tehran. Iranian journal of medical sciences, 1996. 21:69-73.

16. Abdullah MA et al. Seroepidemiology of rubella in Saudi Arabia: an adapted vaccination policy. Journal of epidemiology and community health, 1984, 38:236-9.

17. Hossain A. Seroepidemiology of rubella in Saudi Arabia. Joumal of tropical pediatrics, 1989, 35:169-70.

18. Al-Nakib $W$ et al. Seroepidemiology of viral and toxoplasmal infections during pregnancy among Arab women of childbearing age in Kuwait. International journal of epidemiology, 1983, 12:2203.

19. Gomwalk NE, Ahmad AA. Prevalence of rubella antibodies on the African continent. Review of infectious diseases, 1989, 11:116-21.
20. Dutta SR et al. Seroepidemiology of rubella in Bahrain. International journal of epruterriology, 1965, 14:010-23.

21. Mingle JAA. Frequency of rubella antibodies in the population of some tropical Atrican countries. Review or intectious diseases, 1985, 7(S1):68-71.

22. Aksit $S$ et al. Rubella seroprevalence in an unvaccinated population in Izmir: recommendations for rubella vaccination in Turkey. Pediatric infectious disease journal, 1899 18:577-80.

23. Bhaskaram $P$ et al. Need for protection against rubella in India. Indian journal of pediatrics, 1991, 58:811-4.

24. Lin DB, Chen CJ. Current seroepidemiology of rubella virus infection among female residents in Taiwan. Joumal of medical virology, 1993, 41:174-8.

25. Yuan $\mathrm{C}$ et al. Seroepidemiologic study of rubella in selected Chinese female. Chung Hua I Hsueh Tsa Chih (Taipei), 1989, 43:85-8.

26. Arroyo $M$ et al Natural immunity to measles, rubella and mumps among Spanish children in the pre-vaccination era. International journal of epidemiology. 1986, 15:95-100.

27. Gendrel D et al. Placental transfer of tetanus antibodies and protection of the newborn. Journal of tropical pediatrics, $1990,36: 279-82$.

28. Richard-Lenoble D et al. Passage transplacentaire des anticorps toxoplasmiques. Difference entre la mere africaine et europeenne. [Transplacental passage of toxoplasma antibodies. The difference between African and European mothers]. Bulletin de la Societe de Pathologie Exotique et de ses filiales, 1988, 81:365-8.

29. Shottridge KF, Osmund IF. Seroepidemiology of rubella infection in Chinese and Caucasians in Hong Kong. Journal of hygiene, 1979, 83:397-403.

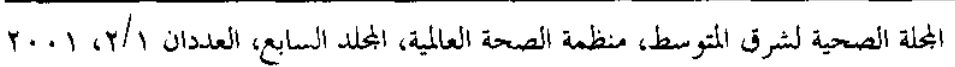


30. Sato $\mathrm{H}$ et al. Transfer of measles, mumps and rubella antibodies from mother to infant. Its effect on measles, mumps and rubella immunization. American journal of diseases in childhood, 1979, 133: 1240-3.
31. Skendzel LP et al. Evaluation of assays for the detection of antibodies to rubella: a report based on data from the cullege of American Pathologists Surveys of 1982. American journal of clinical pathology, 1983, 80(S):594-8.

\section{Control of rubella and congenital rubella syndrome (CRS) in developing countries}

This recent WHO publication includes information on the burden of disease from CRS and vaccination against rubella. It also contains selected bibliographies on rubella and CRS by WHO Region, detalls of selected rubella serosurveys in developing countries and the routine national schedules for rubella immunization by WHO Reglon. The document is available frum: WHO, Department or vaccines and Biologicals, CH-1211 Geneva 27, Switzerland. Fax: +227914193, E-mail: vaccines@who.ch. It is also available on the Internet at:

www. who.int/gPv-documents/

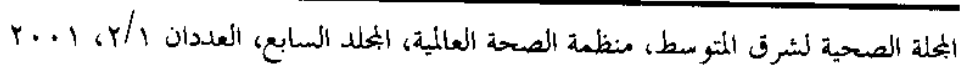

